\title{
Production and characterization of specific monoclonal antibodies binding the Plasmodium falciparum diagnostic biomarker, histidine-rich protein 2
}

\author{
Chiuan Herng Leow ${ }^{1,2,3^{*}}$, Martina Jones ${ }^{4}$, Qin Cheng ${ }^{5}$, Stephen Mahler ${ }^{4}$ and James McCarthy ${ }^{1,2}$
}

\begin{abstract}
Background: Early and accurate diagnosis of Plasmodium falciparum infection is important for providing appropriate treatment to patients with malaria. However, technical limitations of currently available diagnostic tests limit their use in control programs. One possible explanation for the vulnerability of current antibodies used in RDTs is their propensity to degrade at high ambient temperatures. Isolation of new antibodies with better thermal stability represents an appealing approach to improve the performance of RDTs.
\end{abstract}

Methods: In this study, phage display technology was deployed to isolate novel binders by screening a human naïve scFv antibody library against recombinant Plasmodium falciparum histidine rich protein 2 (rPfHRP2). The isolated scFv clones were reformatted to whole $\lg G$ and the recombinant $\mathrm{mAbs}$ were produced in a mammalian $\mathrm{CHO}$ cell expression system. To verify the biological activity of these purified recombinant mAbs, range of functional assays were characterized.

Results: Two unique clones (D2 and F9) were isolated after five rounds of biopanning. The reformatted and expressed antibodies demonstrated high binding specificity to malaria recombinant PfHRP2 and native proteins. When $5 \mu \mathrm{g} / \mathrm{mL}$ of mAbs applied, mAb C1-13 had the highest sensitivity, with an OD value of 1, the detection achieved $5 \mathrm{ng} / \mathrm{mL}$ of rPfHRP2, followed by $\mathrm{mAbs}$ D2 and $\mathrm{F} 9$ at $10 \mathrm{ng} / \mathrm{mL}$ and $100 \mathrm{ng} / \mathrm{mL}$ of $\mathrm{rPfHRP} 2$, respectively. Although the sensitivity of mAbs D2 and F9 was lower than the control, these recombinant human mAbs have shown better stability compared to mouse mAb C1-13 at various temperatures in DSC and blot assays. In view of epitope mapping, the predominant motif of rPfHRP2 recognized by mAb D2 was AHHAADAHHA, whereas mAb F9 was one amino acid shorter, resulting in AHHAADAHH. mAb F9 had the strongest binding affinity to rPfHRP2 protein, with a $K_{D}$ value of $4.27 \times 10^{-11} \mathrm{M}$, followed by control mAb C1-13 at $1.03 \times 10^{-10} \mathrm{M}$ and mAb D2 at $3.05 \times 10^{-10} \mathrm{M}$.

Conclusions: Overall, the performance of these mAbs showed comparability to currently available PfHRP2-specific mouse $\mathrm{mAb}$ C1-13. The stability of these novel binders indicate that they merit further work to evaluate their utility in the development of new generation point of care diagnosis of malaria.

\footnotetext{
* Correspondence: herng.leow@usm.my

${ }^{1}$ QIMR Berghofer Medical Research Institute, Brisbane, Australia

${ }^{2}$ School of Medicine, University of Queensland, Brisbane, Australia

Full list of author information is available at the end of the article
} 


\section{Background}

Malaria, caused by five species of human Plasmodium and, of these species, infection with Plasmodium falciparum is the most prevalent and lethal, causing significant morbidity and mortality worldwide [1]. Therefore, it is crucial to understand the important parameters in the transmission of the disease, and develop effective diagnostic strategies for its prevention and control.

Today, rapid diagnostic tests (RDTs) are increasingly used for malaria diagnosis by detection of parasite biomarkers as they offer a result within 20 minutes. In these tests, Plasmodium lactate dehydrogenase (pLDH), and fructose 1,6-biphosphate aldolase (Aldolase) are commonly used as candidate targets for detection of infection with other Plasmodium species [2-4]. However, P. falciparum histidine-rich protein 2 (PfHRP2) is a biomarker that is predominantly used as a target for detection of P. falciparum infection [5,6]. PfHRP2 is a water-soluble protein that is produced by the asexual stages and gametocytes of $P$. falciparum. This protein is abundantly expressed in the red cell, released during rupture of infected red cells and can remain in the blood for up to 28 days after the initiation of anti-malarial therapy, making it an excellent biomarker for diagnosis [7-9].

A number of technical issues which limit the utility of malaria RDTs have been documented. An important one is their limited shelf life, due to the temperature sensitive capture and detecting antibody reagents $[10,11]$. As RDTs are increasingly being deployed in remote tropical areas, this problem could potentially lead to inaccurate diagnosis and misuse of drugs [12]. Therefore, newly and more stable antigen binders represent important objectives in improving malaria RDT performance.

The aim of this study was to isolate new monoclonal antibodies (mAbs) to PfHRP2 that may have better specificity and stability than those currently used in RDTs. To this end, a human single chain variable fragment $(\mathrm{scFv})$ naïve library was screened to isolate unique binders specific for PfHRP2 using phage display technology. Antibody phage display has been extensively used for isolation of high affinity specific binders against unique antigens from different targets [13-17]. This technology was first introduced by Smith in 1985 and has been widely used in diagnostic and therapeutic applications as previously reviewed $[18,19]$. Such recombinant antibodies have been shown to be effective in targeting different biomarkers in various diseases. Over the past ten years, about 30\% of human therapeutic antibodies that have reached clinical trials have been identified by phage display technology [20,21].

\section{Methods}

\section{Malaria PfHRP2 antigen}

A recombinant PfHRP2 malaria protein encoded by the DNA sequence of the P. falciparum line FCQ79 [22], fused with thioredoxin tag and expressed in Escherichia coli by DNA recombinant technology (Nelson Lee, unpublished) was used. This recombinant protein, rPfHRP2, has been shown to react with a set of PfHRP2-specific mouse monoclonal antibodies [23].

\section{Isolation of PfHRP2-specific scFv antibodies by phage display}

The 'Sheets' naive human scFv phage display library, with a reported diversity of $6.7 \times 10^{9}$ members isolated from peripheral blood lymphocyte cDNA from five different donors, was kindly provided by Prof James Marks (University of California, San Francisco, USA) [24].

Iterative rounds of biopanning were performed to isolate human ScFv specific for rPfHRP2 from the amplified Sheets library. Briefly, two lots of $100 \mu \mathrm{g} / \mathrm{mL}$ purified thioredoxin (Sigma-Aldrich, USA) in phosphate buffered saline (PBS), and one lot of $100 \mu \mathrm{g} / \mathrm{mL}$ rPfHRP2 protein in PBS were incubated overnight at room temperature in immunotubes (Nunc Maxisorp; Denmark). The next day, the immunotubes were rinsed and blocked with $2 \%$ skimmed milk powder (Diploma, Australia) in PBS (MPBS) for 1 hour at room temperature. Phage particles $\left(1.2 \times 10^{13}\right)$ were blocked in $2 \%$ MPBS for 1 hour at room temperature and then incubated for two sequential 1-hour incubations in the thioredoxin-coated immunotubes. The unbound phage were then transferred to the rPfHRP2coated tube and incubated for a further 1 hour at room temperature. Unbound phage were removed by washing five times with $0.1 \%$ Tween 20 in PBS (PBST). Bound phage were eluted with $1 \mathrm{~mL}$ of $200 \mathrm{mM}$ glycine at $\mathrm{pH} 2.5$, and the eluate was immediately neutralized by adding $0.5 \mathrm{~mL}$ of $1 \mathrm{M}$ Tris- $\mathrm{HCl}, \mathrm{pH}$ 7.4. Eluted phage were infected into log phase XL1-Blue E. coli bacteria, and then amplified by growth in $50 \mathrm{~mL}$ of $2 \mathrm{YT}$ medium supplemented with $100 \mu \mathrm{g} / \mathrm{mL}$ ampicillin and $2 \%$ glucose. Phage were rescued by infection with $1 \times 10^{11}$ pfu of M13K07 helper phage (NEB, USA), followed by overnight incubation at $30^{\circ} \mathrm{C}$ in $2 \mathrm{YT}$ medium supplemented with $100 \mu \mathrm{g} / \mathrm{mL}$ ampicillin and $30 \mu \mathrm{g} / \mathrm{mL}$ kanamycin. Rescued phage were concentrated from the culture supernatant by precipitation with 4\% PEG 6000 and $0.5 \mathrm{M} \mathrm{NaCl}$, then used for the next round of panning. In total, five rounds of selections were performed with antigen concentrations of $100 \mu \mathrm{g} / \mathrm{mL}$ for rounds 1 and 2, $50 \mu \mathrm{g} / \mathrm{mL}$ for round 3, $25 \mu \mathrm{g} / \mathrm{mL}$ for round 4 and, $12.5 \mu \mathrm{g} / \mathrm{mL}$ for round 5 .

\section{Analysis of isolated clones}

Following panning, the phage pool and isolated clones were evaluated for binding against recombinant PfHRP2 by polyclonal and monoclonal ELISA, respectively. Briefly, the binding reactivity of phage supernatant was tested in 96-well ELISA plates (Nunc Maxisorp, Denmark) coated with $10 \mu \mathrm{g} / \mathrm{mL}$ of rPfHRP2 and blocked with $2 \%$ MPBS. 
Signals were detected with horseradish peroxidase (HRP)conjugated anti-M13 monoclonal antibody (GE Healthcare, Australia). The DNA sequence of positive clones was determined by Sanger sequencing in Applied Biosystems Sequencer Model 3100 using pHEN1 sequencing primers. After sequencing, the amino acid sequences were deduced and aligned using ClustalW; the three complementarity determining regions (CDRs) and four framework (FW) regions in each of variable heavy $(\mathrm{VH})$ and variable light (VL) chain regions were identified using the IMGT V-Quest software and VBASE2 immunoglobulin database [25].

\section{Antibody reformatting}

To reformat the scFv fragments to whole, fully human IgG, the variable regions for both the heavy and kappa light chains of the rPfHRP2 specific scFv clones D2 and F9 were PCR amplified from the phagemid vectors and cloned into SacI-linearized ReformAb vectors (Acyte Biotech, Australia) as previously described [26].

\section{Mammalian cell expression and purification}

The expression and purification of mAbs D2 and F9 was undertaken as previously described [26]. Briefly, the heavy and light chain plasmids were co-transfected into suspension-adapted Chinese hamster ovary $(\mathrm{CHO})$ cells after mixing of plasmids with polyethylenimine (PEI). After four hours, cells were diluted by doubling the total volume with $\mathrm{CD}-\mathrm{CHO}$ media, and insulin-like growth factor 1 (IGF-1) (Novozymes, USA) was added at a concentration of $0.1 \mathrm{mg} / \mathrm{L}$. The cultures were then transferred to a humidified incubator and maintained at $32^{\circ} \mathrm{C}$ and $7.5 \% \mathrm{CO}_{2}$ for seven to 14 days with shaking (250 rpm). Antibodies were purified using Protein A affinity chromatography. Bound antibodies were eluted at low $\mathrm{pH}$ and then immediately buffer exchanged into PBS. Protein concentration was determined by absorbance at $280 \mathrm{~nm}$, and used to determine the yield. The quality of purified monoclonal antibodies (D2 and F9) was determined by SDS-PAGE gel and size-exclusion high-performance liquid chromatography (HPLC) analysis.

\section{Antibody binding sensitivity determined by endpoint dilution ELISA}

To understand the binding efficacy of these mAbs, a malaria PfHRP2-specific mAb C1-13 (kindly provided by Dr Martin Bubb, National Products Institute, South Africa) was used as positive control in this study. mAb C1-13 is a commercial mouse IgG1 mAb with binding specificity against PfHRP2, that has been reported in previous studies [23,27].

Microtitre plates (Greiner Bio-One, Germany) were coated with $100 \mu \mathrm{L}$ of diluted $\mathrm{rPfHRP} 2$ protein $(1 \mu \mathrm{g} / \mathrm{mL})$ and blocked with $2 \%$ MPBS. After three wash steps with
0.1\% PBST, the blocked wells were incubated with $100 \mu \mathrm{L}$ of two-fold serial diluted mAbs D2 and F9, and control antibody C1-13, starting at $20 \mathrm{ng} / \mathrm{mL}$ for 1 hour at room temperature. Plates were washed with $0.1 \%$ PBST. Onehundred $\mu \mathrm{L}$ of secondary detection antibody was added, using goat anti-human antibody-conjugated HRP (Cat \#: A8667) (Sigma-Aldrich; MO, USA), diluted 1:5,000 in 2\% MPBS for D2 and F9 wells, or secondary goat anti-mouse antibody-conjugated HRP (Cat \#: 115-035-003) (Jackson, USA), diluted 1:5,000 in 2\% MPBS for C1-13 wells. Plates were incubated at room temperature for 1 hour. After washing with $0.1 \%$ PBST, $100 \mu \mathrm{L}$ of freshly prepared OPD solution (Sigma, USA) was added to each well, and absorbance read at a wavelength of $405 \mathrm{~nm}$ using ELISA plate reader (Biotek Synergy HT, USA).

\section{Antibody binding specificity to rPfHRP2 and native proteins by Western blot}

Saponin lysis was used to lyse the erythrocyte cell membranes, a process that leaves the cell membrane intact. $P$. falciparum culture was undertaken with the reference strain 3D7 in human O + blood (Red Cross Blood Service, Brisbane). Cultures were synchronized and harvested at $5-10 \%$ parasitaemia. The parasite sample was then washed and purified as described previously [28], and mixed 1:1 with $2 \times$ reducing SDS-PAGE sample buffer.

Following SDS-PAGE electrophoresis, the separated rPfHRP2 proteins $(1 \mu \mathrm{g} / \mathrm{mL})$, and native protein $(1 \mu \mathrm{g} / \mathrm{mL})$ were transferred to nitrocellulose membrane (Hybond-c Amersham Bioscience, UK). Uninfected red cells from the same lot were used as controls. Membranes were blocked in 5\% MPBS and incubated for 1 hour at room temperature. After three wash steps with $0.1 \%$ PBST, $30 \mathrm{~mL}$ of test mAbs at a concentration of $10 \mu \mathrm{g} / \mathrm{mL}$ was incubated on the membrane at room temperature for 1 hour with gentle shaking. Following three wash steps with $0.1 \%$ PBST, membranes were incubated with secondary goat antihuman antibody-conjugated HRP (Cat\#: A8667) (SigmaAldrich, USA) that was diluted 1:10,000 in 5\% MPBS for mAbs D2 and F9 or goat anti-mouse antibody-conjugated HRP (Cat\#: 115-035-003) (Jackson, USA) that was diluted $1: 10,000$ in $5 \%$ MPBS for mAb C1-13. The detection of HRP-conjugated secondary antibody was performed using ECL chemiluminescence detection kit (Amersham Bioscience, USA).

\section{Antigen sensitivity determined by ELISA}

Microtitre plates (Nunc Maxisorp, USA) were coated with ten-fold serially diluted rPfHRP2 protein $(100 \mu \mathrm{L} /$ well $)$, with a starting concentration of $1 \mu \mathrm{g} / \mathrm{mL}$. Plates were then blocked in 2\% MPBS and washed three times with 0.1\% PBST. The primary test antibodies (D2, F9 and C1-13) were prepared at concentrations of $1 \mu \mathrm{g} / \mathrm{mL}$ and $5 \mu \mathrm{g} / \mathrm{mL}$ and $100 \mu \mathrm{L}$ were added to corresponding wells and the 
detection of secondary antibody was undertaken as described above.

\section{Sensitivity determined by dot blot}

$10-15 \mu \mathrm{L}$ of 1,000 -fold serially diluted rPfHRP2 protein (starting at $1 \mu \mathrm{g} / \mathrm{mL}$ ) was transferred to the nitrocellulose membrane (Hybond-C, Amersham Bioscience, UK) by vacuum aspiration. After blocking in 5\% MPBS for 1 hour, the membranes were cut into small strips and placed into corresponding tubes which contained $30 \mathrm{~mL}$ of appropriate test antibodies (D2, F9 and C1-13) at concentrations of $1 \mu \mathrm{g} / \mathrm{mL}$ and $5 \mu \mathrm{g} / \mathrm{mL}$. The blot images were developed as described above.

\section{Sandwich configuration studies}

Microtitre plates coated with $100 \mu \mathrm{L}$ of capture antibodies D2, F9 or C1-13 (10 $\mu \mathrm{g} / \mathrm{mL})$ were blocked by $300 \mu \mathrm{L}$ of $5 \%$ MPBS. Ten-fold serially diluted rPfHRP2 protein dilutions (starting at $1 \mu \mathrm{g} / \mathrm{mL}$ ) were transferred to the corresponding wells and incubated for 1 hour. After three washes with PBST, bound antigen was detected by incubation with $100 \mu \mathrm{L}$ of mAbs D2 or F9 $(10 \mu \mathrm{g} / \mathrm{mL})$ (for plates coated with $\mathrm{C} 1-13)$, or $\mathrm{C} 1-13(10 \mu \mathrm{g} / \mathrm{mL})$ (for plates coated with D2 and F9). After incubation at room temperature for 1 hour, plates were washed as described above. Detection was achieved using $100 \mu \mathrm{L}$ of mouse anti-human antibodyconjugated HRP (Sigma-Aldrich, MO, USA) for wells with mAbs D2 and F9 detection antibodies or goat anti-mouse antibody conjugated HRP for wells using C1-13 detecting antibody in $2 \%$ MPBS as described above.

Heat lability determined by differential scanning calorimetry The melting point of purified mAbs D2, F9 and C1-13 was measured by differential scanning calorimetry (DSC) using a NanoDSC Microcalorimeter (TA Instrument, USA) at an antibody concentration of $1.0 \mathrm{mg} / \mathrm{mL}$. The antibodies were scanned at a rate of $1^{\circ} \mathrm{C}$ per minute from $25^{\circ} \mathrm{C}$ to $110^{\circ} \mathrm{C}$, and analysed using DSC software.

\section{Binding efficacy of mAbs stored at different temperatures by dot blot analysis}

Ten to $15 \mu \mathrm{L}$ of two-fold serially diluted rPfHRP2 protein (starting at $1 \mu \mathrm{g} / \mathrm{mL}$ ) was transferred to nitrocellulose membrane by vacuum aspiration. After blocking in $5 \%$ MPBS at room temperature for 1 hour, membranes were cut into small strips and placed into corresponding tubes which contained $30 \mathrm{~mL}$ of test D2, F9 and control C1-13 antibodies $(10 \mu \mathrm{g} / \mathrm{mL})$ that had been separately incubated at $25^{\circ} \mathrm{C}$ for seven days, and $37^{\circ} \mathrm{C}$ for 30 days. The secondary antibody incubation and detection were undertaken as described above.

\section{Epitope mapping}

A total of 171 different peptides with length of 15 amino acid residues designed to represent different sequences and regions of PfHRP2 were used in epitope mapping as previously described [23].

\section{Antibody binding affinity determined by Octet}

The binding affinity of human mAbs with rPfHRP2 was determined using anti-human IgG capture (AHC) biosensors in the Octet Red Instrument (Fortebio, USA). Purified mAbs $(20 \mu \mathrm{g} / \mathrm{mL})$ and ten-fold serially diluted rPfHRP2 (starting at $50 \mu \mathrm{g} / \mathrm{mL}$ ) were prepared in assay buffer $(10 \mathrm{mM}$ phosphate, $150 \mathrm{mM} \mathrm{NaCl}, 0.02 \%$ Tween $20,0.05 \%$ sodium azide, and $1 \mathrm{mg} / \mathrm{mL}$ bovine serum albumin (BSA), pH7.4). Briefly, a 96-well black microtitre plate (Perkin Elmer, USA) was prepared and $200 \mu \mathrm{L}$ of each sample and buffer were loaded into corresponding wells. After inserting the hydration plate, both hydrated biosensor assembly and sample plate were equilibrated prior to the assay starting. The default settings with minor modifications were used for the assays. The data acquisition at 1 minute/six biosensors, flow rate was at $200 \mathrm{~mm} /$ second, precision was at $<10 \%$ coefficient of variations $(\mathrm{CVs})$, and standard curve fit was calibrated at four-parameter logistic (4-PL) model. The binding rate analysis was performed by Octet Data Analysis software version 6.1.

\section{Results}

\section{Biopanning and selection of anti-PfHRP2 scFv clones}

A naïve human $\mathrm{scFv}$ antibody phage display library was screened against the immobilized malaria antigen rPfHRP2. After five rounds of biopanning, the phage pool showed significant enrichment of binders to rPfHRP2 by polyclonal phage ELISA analysis (Figure 1). Eighty-four clones were randomly picked from the fifth round phage pool and 81 showed strong binding in a monoclonal phage ELISA assay.

Twenty-four positive clones and one negative clone were chosen for further analysis. PCR-amplified inserts with an expected size of $\sim 500$ bp were achieved in all clones except one. Of these clones, 13 were found to have an identical sequence. An additional four clones also appeared to have this same sequence, although the sequence data was incomplete. Thus, the population contained one highly dominant clone. An additional sequence was represented by two clones: F9 and B6. One other clone contained an out-of-frame coding region and corresponded with the ELISA negative clone. Two clones (D2 and F9) representing the two unique sequences were selected for further analysis. Sequence analysis of the $\mathrm{VH}$ and VL fragments revealed that both clones belonged to human immunoglobulin IgHV3 and IgKV1 families, respectively. 


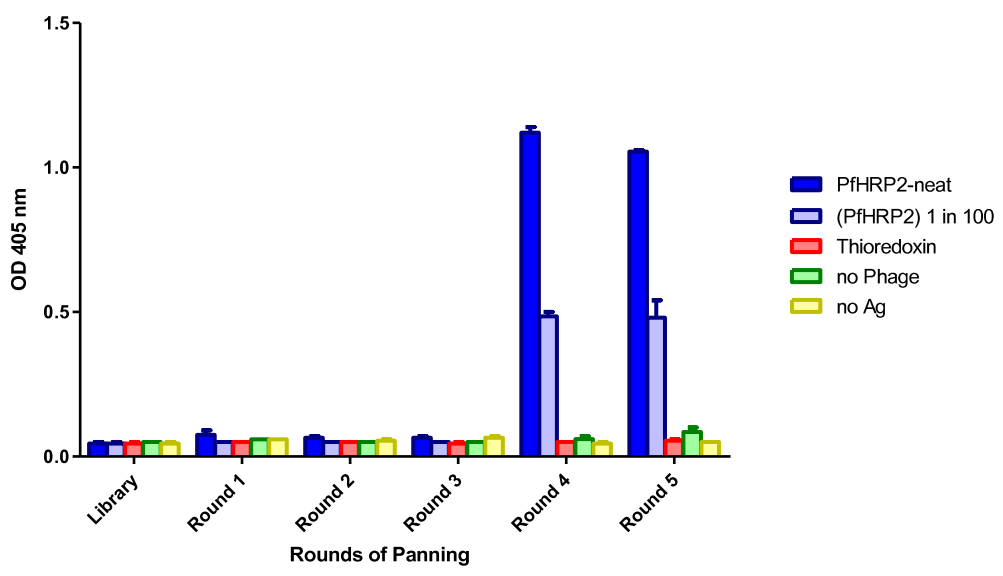

Figure 1 Polyclonal phage ELISA. The diagram shows an increase in ELISA absorbance values in rounds 4 and 5 phage pools against neat, and 1 in 100 diluted rPfHRP2 proteins. Immobilized thioredoxin protein, no phage, and uncoated microtitre plate wells were used as negative controls.

\section{Antibody expression}

The D2 and F9 scFv fragments were reformatted to whole mAbs, expressed in $\mathrm{CHO}$ cells and purified by Protein A chromatography [26]. SDS-PAGE analysis of the purified $\mathrm{mAbs}$ showed the whole intact $\mathrm{mAb}$ in nonreducing conditions $(\sim 150 \mathrm{kDa})$, and a $50 \mathrm{kDa}$ heavy chain and $25 \mathrm{kDa}$ light chain in reducing conditions. Size exclusion HPLC showed no significant aggregation or degradation (Figure 2).

\section{Characterization of antibody}

ELISA was employed to define the titre (endpoint dilution) of each $\mathrm{mAb}$ against $100 \mu \mathrm{g} / \mathrm{ml}$ of rPfHRP2 (Figure 3). When the cut-off absorbance is set at 0.5, $\mathrm{mAb}$ D2 had the highest end-titre sensitivity at $0.06 \mathrm{ng} / \mathrm{mL}$, followed by mAb C1-13 at $0.1 \mathrm{ng} / \mathrm{mL}$ and $\mathrm{mAb}$ F9 at $0.15 \mathrm{ng} / \mathrm{mL}$. No reactions were observed for these $\mathrm{mAbs}$ in ELISA assays and Western blot when rPfHRP2 was replaced by $1 \%$ BSA.

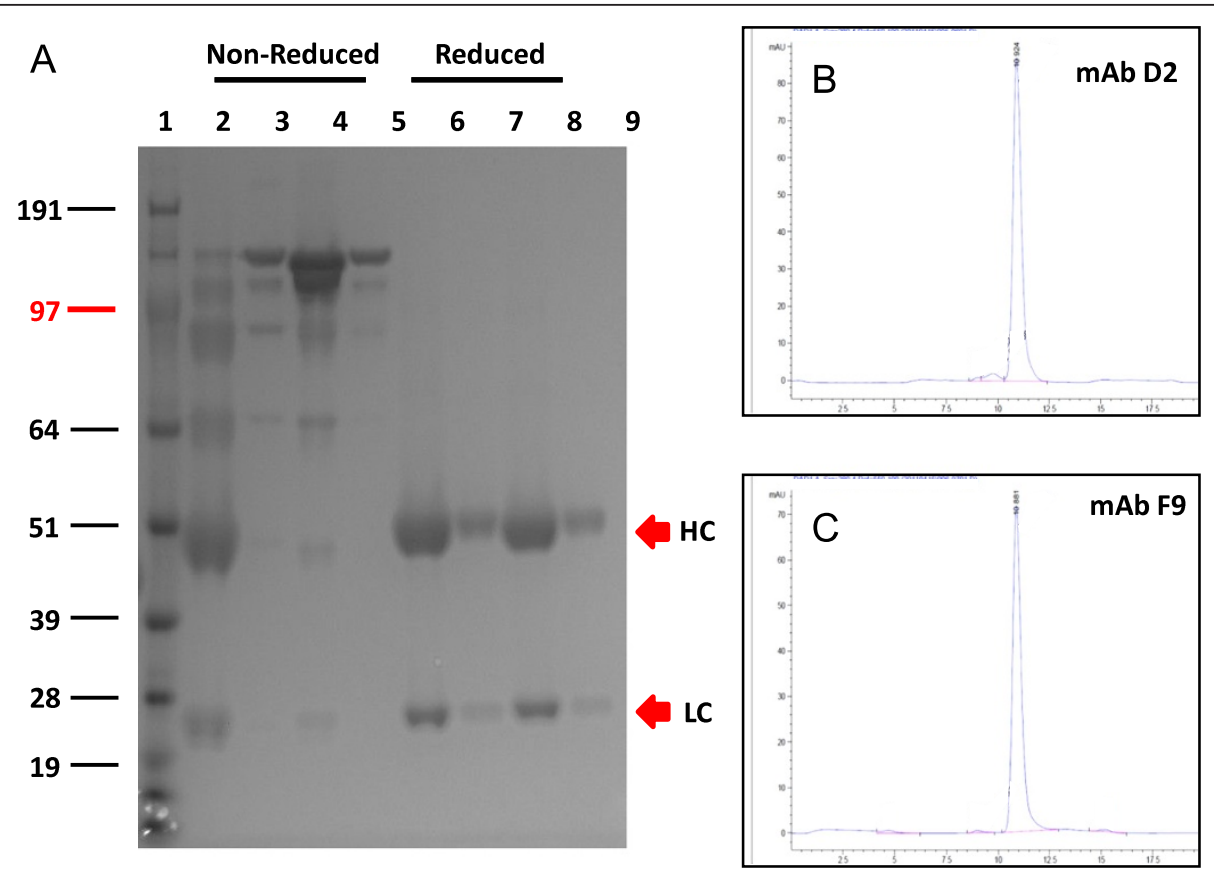

Figure 2 Analysis of purified recombinant mAbs D2 and F9 on 4-12\% SDS-PAGE. The gel was stained with Coomassie Blue R250 (A). Lane 1: SeeBlue Plus2 Pre-Stained Standard (Invitrogen); Lanes 2 and 3: non-reduced mAb D2; Lanes 4 and 5: non-reduced mAb F9; Lanes 6 and 7: reduced mAb D2; Lanes 8 and 9: reduced mAb F9, at neat, and 1 in 10 dilutions. Analytical size exclusion chromatography of protein-A purified recombinant $\mathrm{mAbs} \mathrm{D} 2$ and $\mathrm{F} 9$ at $280 \mathrm{~nm}$ are shown in panels $\mathbf{B}$ and $\mathbf{C}$, respectively. 


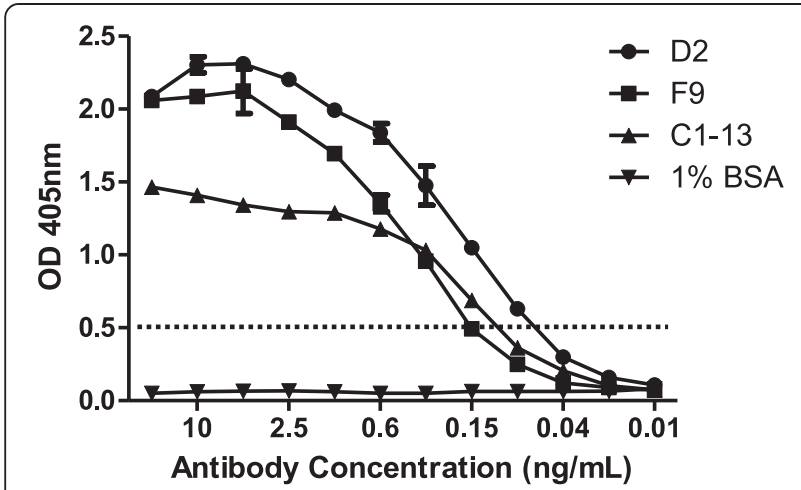

Figure 3 Titration of mAbs D2, F9, and C1-13 against $0.1 \mu \mathrm{g}$ rPfHRP2 protein. The antibodies were prepared in two-fold serial dilution, from $20 \mathrm{ng} / \mathrm{mL}$ in ELISA assay. 1\% BSA protein was used as a negative control. The dotted line represents cut-off OD absorbance at 0.5 .

The specificity of mAbs against recombinant and native malaria proteins was evaluated by Western blot analysis (Figure 4). Both mAbs D2 and F9 reacted to rPfHRP2, showing a single band at $82 \mathrm{kDa}$, the correct size for the thioredoxin-fused protein. For detection of native parasite proteins from blood stage infection, $P$. falciparum-infected red blood cells were tested in Western blot. The results show that all mAbs were capable of recognizing native PfHRP2 protein at $\sim 50 \mathrm{kDa}$, with such band was not detected from uninfected $\mathrm{RBC}$ protein lane. No cross-reactivity with the other two malaria biomarkers, namely $P$. falciparum lactate dehydrogenase (PfLDH) and Plasmodium vivax aldolase (PvAldolase) was observed on Western blot (Additional file 1) or ELISA (Additional file 2).

The sensitivity of detecting rPfHRP2 protein by mAbs was investigated by ELISA and dot blot analysis (Figure 5). The ELISA data indicated a difference in sensitivity between three mAbs when comparing the detection limit against serial diluted rPfHRP2. While $5 \mu \mathrm{g} / \mathrm{mL}$ of mAbs applied, mAb $\mathrm{C} 1-13$ had the highest sensitivity, with an OD value of 1 , the detection achieved $5 \mathrm{ng} / \mathrm{mL}$ of rPfHRP2, followed by mAbs D2 and F9 at $10 \mathrm{ng} / \mathrm{mL}$ and $100 \mathrm{ng} / \mathrm{mL}$ of rPfHRP2, respectively (Figure 5A). However, sensitivity fell when less concentrated antibodies were applied $(1 \mu \mathrm{g} / \mathrm{mL})$ (Figure $5 \mathrm{~B})$. These results were consistent with results of the semi-quantitative studies carried out by dot blot. Compared to the commercial antibody C1-13, the sensitivity of both antibodies D2 and F9 was lower. Detection limits were ten times (D2) and 100 times (F9) lower than for $\mathrm{C} 1-13$.

To determine the accuracy and linearity of rPfHRP2 detection, mAbs of D2 and F9 were each designed as capture or detection antibodies in sandwich ELISA, in combination with $\mathrm{mAb} \mathrm{C} 1-13$. The mean reactivity for duplicate measures of serially diluted rPfHRP2 protein from $1 \mu \mathrm{g} / \mathrm{mL}$ to $0.01 \mathrm{fg} / \mathrm{mL}$ detected by mAbs $\mathrm{D} 2$ and F9 are represented in Figure 6. From the results, both antibodies D2 and F9 showed binding to rPfHRP2 protein in heterologous configurations with mAb C1-13. However, the sensitivity of heterologous antibodies varied despite the use of the same mAbs D2 or F9 as either capture or detection antibodies. When using an OD cutoff value of 0.25 , the detection limit for D2-Cap/C113-Detection was at $50 \mathrm{pg} / \mathrm{mL}$, whereas C1-13-Cap/ D2-Detection was at $1 \mathrm{pg} / \mathrm{mL}$ (Figure 6A). The configuration of mAbs F9 and C1-13 influenced different sensitivity. The lowest detection limit for F9-Cap/C1-13-Detection was $5 \mathrm{ng} / \mathrm{mL}$, and C1-13-Cap/F9-Detection was $0.5 \mathrm{ng} /$ $\mathrm{mL}$ at the OD cut-off value of 0.25 (Figure 6B). Overall, the configuration of C1-13-Cap/D2-Detection was the most sensitive for detection of rPfHRP2 protein by ELISA. Neither heterologous mAbs D2 nor F9 reacted to $1 \%$ BSA protein.

\section{Heat lability of antibodies}

The melting point value of mAbs was determined using DSC analysis (Additional file 3). Two melting point peaks (Tm) were detected for the mAbs, namely $72^{\circ} \mathrm{C}$ and $82^{\circ} \mathrm{C}$ for $\mathrm{mAb} \mathrm{D} 2$, and $73^{\circ} \mathrm{C}$ and $80^{\circ} \mathrm{C}$ for $\mathrm{mAb} \mathrm{F} 9$. Only one melting point of $72^{\circ} \mathrm{C}$ was observed for the control antibody $\mathrm{C} 1-13$. The precipitation of mAbs D2 and F9 at high temperatures was indicated by a sharp peak decline and negative $\mathrm{Cp}$ values. This phenomenon was not observed with mAb $\mathrm{C} 1-13$, where the $\mathrm{Cp}$ values returning to baseline following Tm peak.

After incubation at different temperatures for different durations, the heat stability of two recombinant mAbs were determined by reacting to two-fold serially diluted rPfHRP2 proteins immobilized on nitrocellulose membrane using dot blot (Additional file 4). mAb C1-13 had previously been shown to retain its reactivity after incubating at $37^{\circ} \mathrm{C}$ for 90 days [23]. After incubation at $25^{\circ} \mathrm{C}$ for seven days, the binding ability of mAbs D2, F9 and C1-13 was still maintained (Additional file 4A). The heat stability of mAbs was different; mAb D2 retained its binding sensitivity at $37^{\circ} \mathrm{C}$ compared to $25^{\circ} \mathrm{C}$, whereas loss of sensitivity at $37^{\circ} \mathrm{C}$ was observed in mAbs $\mathrm{C} 1-13$ and F9 (Additional file 4B).

\section{Epitope mapping}

In initial epitope mapping, both mAbs D2 and F9 gave positive reactions to a range of different peptides. $\mathrm{mAb}$ D2 recognized the predominant motif AHHAADAHHA as its major epitope with possible substitutions of serine in the fifth amino acid, a similar result to the major epitope recognized by $\mathrm{mAb} \mathrm{C} 1-13$ [23]. In contrast, the major epitope recognized by mAb F9 was one amino acid shorter, lacking an alanine at the end, resulting in AHHAADAHH. 


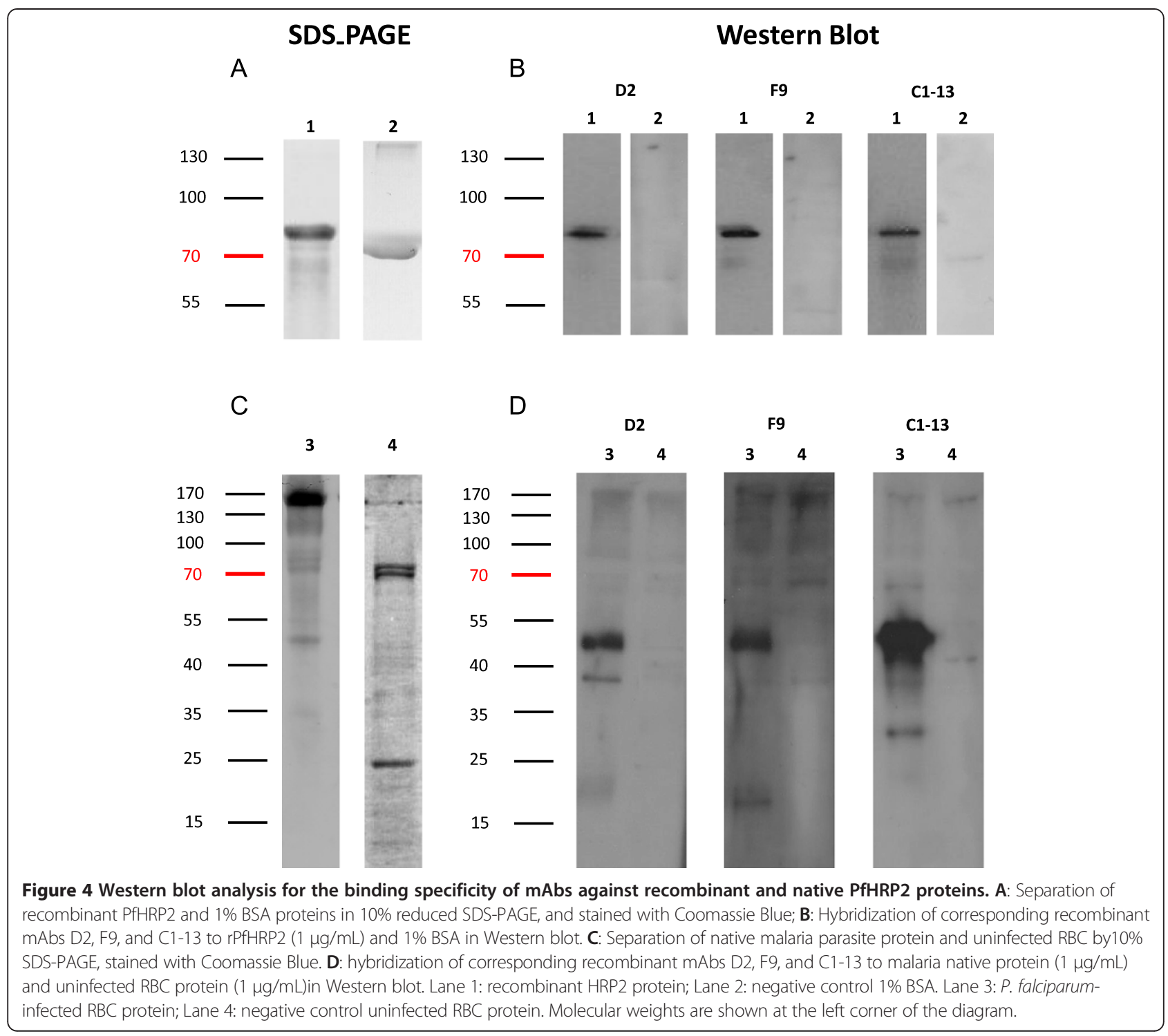

\section{Evaluation of binding affinity of mAbs}

A kinetic study was performed to determine the binding affinity of mAbs to serially diluted rPfHRP2 proteins from 610-0.0061 nM (Additional file 5). Of the three mAbs, the highest association constant $\left(\mathrm{k}_{\mathrm{a}}\right)$ value was displayed by F9 at $1.80 \times 10^{6} \mathrm{Ms}^{-1}$ (Additional file 5B), whereas D2 was at $8.50 \times 10^{5} \mathrm{Ms}^{-1}$ (Additional file 5A). In comparison, C1-13, previously measured by Biacore (Lee et al. unpublished) has an association value of $3.60 \times 10^{5} \mathrm{Ms}^{-1}$ (Lee et al. unpublished). The dissociation constant $\left(\mathrm{k}_{\mathrm{d}}\right)$ value of $\mathrm{F} 9$ was however the lowest value at $7.66 \times 10^{-5} \mathrm{~s}^{-1}$ compared to D2 $\left(2.59 \times 10^{-4} \mathrm{~s}^{-1}\right)$ and $\mathrm{C} 1-13\left(3.72 \times 10^{-5} \mathrm{~s}^{-1}\right)$.

To understand the binding affinity value, the $K_{D}$ was calculated by $\mathrm{k}_{\mathrm{d}} / \mathrm{k}_{\mathrm{a}}$. This showed that mAb F9 had the strongest binding affinity to rPfHRP2 protein, with a $K_{D}$ value of $4.27 \times 10^{-11} \mathrm{M}$ (Table 1 ), followed by control mAb C1-13 at $1.03 \times 10^{-10} \mathrm{M}$ and $\mathrm{mAb}$ D2 at $3.05 \times 10^{-10} \mathrm{M}$.

\section{Discussion}

Since the introduction of lateral flow immunochromatographic assays for detection of malaria about 20 years ago $[29,30]$, RDTs have played an increasing role in improving the quality of case management for malaria and assist the reduction of unnecessary anti-malarial drug usage $[31,32]$. The specificity, sensitivity, affinity, and heat stability of antibodies are important determinants of the quality and reliability of a RDT.

Current malaria RDTs are developed in formats such as dipstick, strip, card, pad, well, or cassette [33]. Three types of antibodies, including signal, capture and control antibodies are generally incorporated in the device to render indication of a complex antibody-antigen interaction [10,33]. 
A

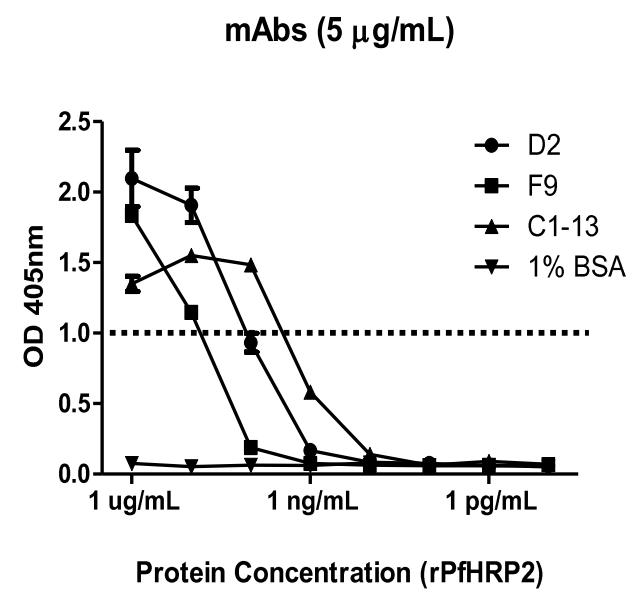

B

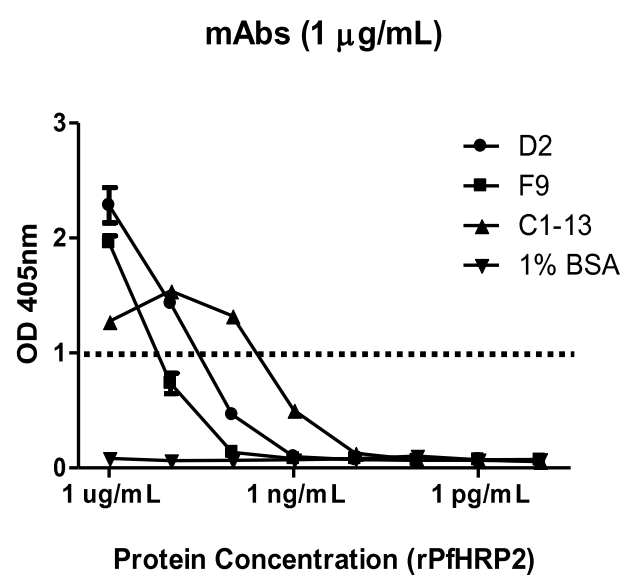

Protein Concentration (rPfHRP2)

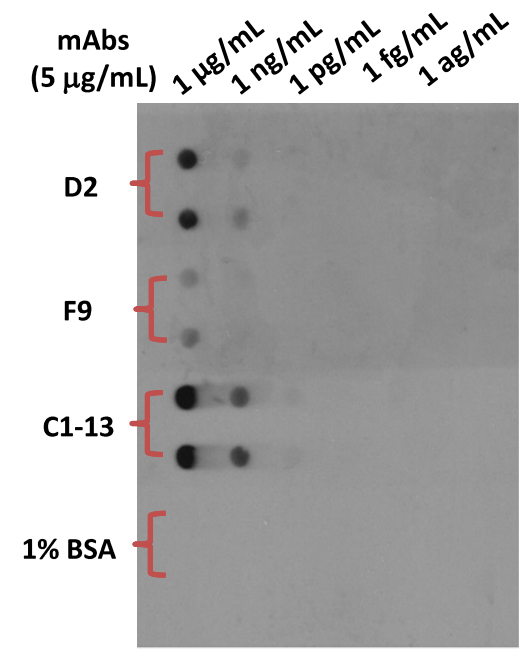

Protein Concentration (rPfHRP2)

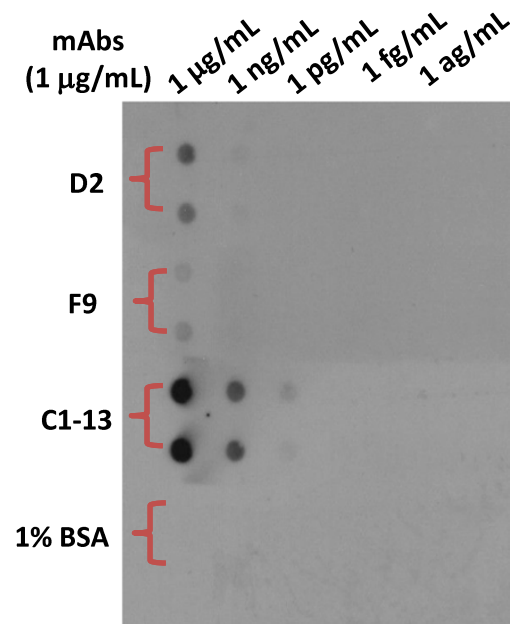

Figure 5 Sensitivity of mAbs D2, F9 and C1-13 against rPfHRP2. The binding efficacy of mAbs against serially diluted recombinant PfHRP2 is determined by ELISA (Left panel) and dot blot (Right panel). A: $5 \mu \mathrm{g} / \mathrm{mL}$ of mAbs; B: $1 \mu \mathrm{g} / \mathrm{mL}$ of mAbs. Dot line represents cut-off OD absorbance at 1.0.

However, variation of sensitivity has been reported in many current commercial available RDTs [34]. The degradation of antibody performance with long exposure to high temperature has led to a decrease in operational performance [35]. To address this problem, a selection of quality mAbs with high affinity, specificity and heat stability to target antigen is important to improve malaria diagnostic in tropical regions.

The aim of this study was to generate new mAbs and assess their binding capability against malaria PfHRP2 antigen. The Sheets naive human $\mathrm{scFv}$ phage display library has been shown to contain binders to a wide range of different antigens, with affinities achieved in subnanomolar range [24]. This provided a good rationale for using this library to isolate novel scFv fragments targeting parasite biomarkers. Following five rounds of biopanning of the Sheets library, two unique scFv clones with specificity to rPfHRP2 were isolated. These clones were reformatted to whole IgG1 to allow comparison with a commercially available mouse antibody against PfHRP2.

Most antibodies deployed currently in commercial malaria RDT devices were produced in the early 1990s. Due to commercial consideration, details such as mAbs isotype, subclasses, epitopes targeted, and laboratory of origin are either rarely published or incompletely documented by manufacturers [22]. Herein, the performance of the two newly isolated human mAbs produced in this study was compared with commercially available mouse mAb C1-13, which was shown to have the highest 


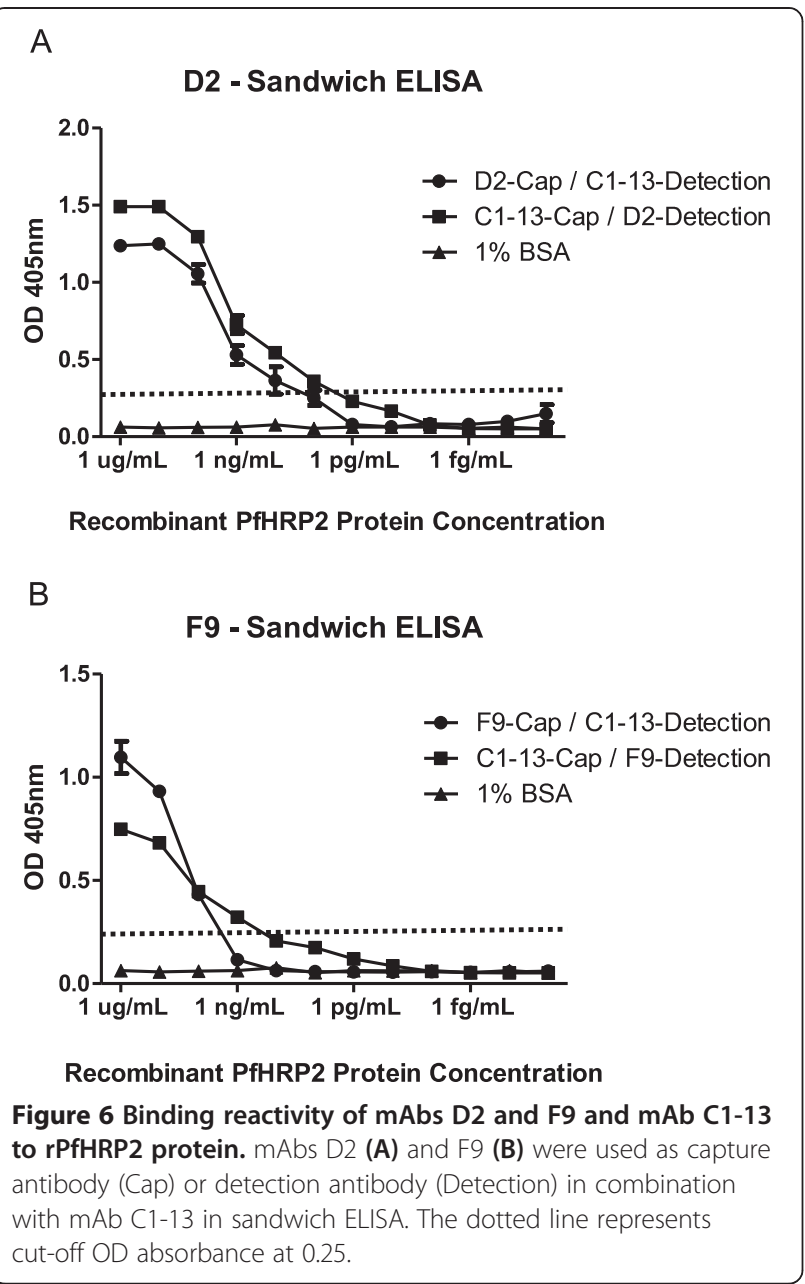

sensitivity and specificity among a panel of monoclonal IgGs targeting PfHRP2 [23].

Both mAbs D2 and F9 exhibited strong binding specificity and sensitivity against both recombinant and native PfHRP2, as shown by ELISA and Western blot (Figures 3 and 4). Like C1-13, both reformatted mAbs recognized rPfHRP2 as a single band on Western blot, suggesting that the specificity of mAbs D2 and F9 was not affected by reformatting. In extracts from infected red blood cells, all mAbs recognized a major band of $50 \mathrm{kDa}$, the size of native PfHRP2. The presence of multiple bands on Western blot is not uncommon when anti-PfHRP2

\section{Table 1 Kinetics determination of mAbs D2 and F9}

\begin{tabular}{cccc}
\hline $\mathbf{m A b}$ & $\mathbf{k}_{\mathbf{a}}(\mathbf{1} / \mathbf{M s})$ & $\mathbf{k}_{\mathbf{d}}(\mathbf{1} / \mathbf{s})$ & $\mathbf{K}_{\mathbf{D}}(\mathbf{M})$ \\
\hline D2 & $8.50 \times 10^{5}$ & $2.59 \times 10^{-4}$ & $3.05 \times 10^{-10}$ \\
F9 & $1.80 \times 10^{6}$ & $7.66 \times 10^{-5}$ & $4.27 \times 10^{-11}$ \\
C1-13 & $3.60 \times 10^{5}$ & $3.72 \times 10^{-5}$ & $1.03 \times 10^{-10}$
\end{tabular}

Association $\left(k_{\mathrm{a}}\right)$, dissociation rates $\left(\mathrm{k}_{\mathrm{d}}\right)$, and equilibrium constants $\left(\mathrm{K}_{\mathrm{D}}\right)$ of $\mathrm{mAbs}$ D2, F9, and C1-13 against rPfHRP2. The analysis for mAbs D2 and F9 were undertaken using the Octet Red platform, whereas mAb C1-13 was determined by BIAcore.
mAbs are used against native parasite proteins, because P. falciparum has several histidine-rich proteins [36]. One of these is PfHRP3, a protein highly similar to PfHRP2 in amino acid sequence with a molecular weight of approximately 35-37 kDa [37]. Antibodies against PfHRP2, such as mAb $\mathrm{C} 1-13$, have been reported to bind to PfHRP3 [23]. However, only two bands (50 kDa and $37 \mathrm{kDa}$ ) were recognized by $\mathrm{mAb} \mathrm{D} 2$, while one band $(50 \mathrm{kDa})$ by $\mathrm{mAb} F$, suggesting these mAbs may have higher specificity than C1-13 [38,39].

When D2 and F9 antibodies were tested either as capture antibody or detection antibody by partnering with mAb C1-13 (Figure 6), both antibodies showed no significant loss of sensitivity of binding in the sandwich format. The detection sensitivity was best when mAb C1-13 was used as capture antibody although different secondary antibodies used for detection may contribute to the detection sensitivity. As an extensive number of repeated epitopes exist in PfHRP2 [6], epitope numbers are not likely contributing to the difference in binding of mAbs [40]. The difference may result from better binding affinity of mAb C1-13 to the double HHA (amino acid residues) sequence on antigenic site of PfHRP2 epitopes. However, mAb C1-13 was shown to possess lower affinity than $\mathrm{mAb}$ F9. Therefore the causes contributing the binding behaviour of these $\mathrm{mAbs}$ remain unclear.

The Octet $\operatorname{Red}^{\circ}$ system was chosen to examine, in real time, the rate of association (binding) and dissociation (unbinding) of mAbs D2 and F9 to rPfHRP2 protein. The mAb F9 showed the highest binding affinity $\left(K_{D}\right.$ of $40 \mathrm{pM}$ ), although it had a weaker sensitivity in the ELISA screening (Figure 5). This was followed by mAbs C1-13 $(0.1 \mathrm{nM})$ and $\mathrm{D} 2(0.3 \mathrm{nM})$. These are very strong affinities, despite being isolated from a naive library, which may in part be explained by the nature of the epitope. The optimal epitope recognized by $\mathrm{mAb} \mathrm{D} 2$ was identical to that recognized by mAb $\mathrm{C} 1-13$, namely AHHAADAHHA. Despite having the same epitope, $\mathrm{mAbs} \mathrm{C} 1-13$ and $\mathrm{D} 2$ are able to simultaneously bind to PfHRP2 in a sandwich ELISA, since this epitope is present in many repeats along the PfHRP2 sequence as evidenced by the large number of analysed peptides from PfHRP2 that were able to bind these mAbs (41-60\%) [23]. The repetitive nature of this epitope contributes to the very slow dissociation rates of these mAbs, as the antigen is providing high avidity, and consequently an apparent strong affinity. These factors are contributing to the poor fit of a kinetic binding model, which assumes a 1:1 interaction, shown in Additional file 5 , so the kinetic values are an estimate only.

This strong apparent affinity is ideal for RDTs as mAbs that have a faster rate of association and slower rate of disassociation (a low $k_{d}$ value) would be considered to give a greater binding ability to target biomarker. Thus, the kinetic properties of mAbs D2 and F9 make them 
potential candidates for malaria RDTs, and are at least comparable to the commercially available mAb C1-13, which has been shown to be superior to PfHRP2-specific IgM isotype antibodies [23].

Another aspect that important for reagents used in RDTs in the tropical and subtropical world is their ability to withstand high ambient storage temperatures. The experiment identified $72^{\circ} \mathrm{C}$ as the melting point for mouse $\mathrm{mAb} \mathrm{C} 1-13,82^{\circ} \mathrm{C}$ and $80^{\circ} \mathrm{C}$ for $\mathrm{D} 2$ and $\mathrm{F} 9$, respectively (Additional file 3 ). When temperature gradually increased $\left(>82^{\circ} \mathrm{C}\right)$, protein precipitation was not observed in control mAb C1-13 but was for both mAbs D2 and F9. Peaks in the readout trace may correspond to different parts of the $\mathrm{mAb}$ (eg the Fab region and Fc region) unfolding. According to literature, the $\mathrm{CH} 2$ domain of an antibody tends to unfold earlier, followed by the Fab and the $\mathrm{CH} 3$ domains. The thermal transition of the Fab domain commonly occurs between the $\mathrm{CH} 2$ and $\mathrm{CH} 3$ domains or overlapping with either one of this domain in a monoclonal antibody [41]. Furthermore, major difference in the amino acid composition between mouse and human immunoglobulins is another likely factor that resulted in these mAbs having different thermal stability [42-44]. The nonprecipitation of mAb $\mathrm{C} 1-13$ indicated by $\mathrm{Cp}$ values returning to baseline shows this $\mathrm{mAb}$ possesses reversibility, which might not be found in the human mAbs D2 and F9. Due to lack of information about this commercial $\mathrm{mAb}$, the complete amino acid composition and the production method were not available. However, this varying melting temperature may be influenced by thermodynamic interactions within the antibody domains, and conformational changes in human and mouse mAbs that correspond to the aggregation and precipitation of the unfolded protein $[45,46]$.

In terms of stability, the unfolding of the human and mouse IgG1 at pH 5.5 generally present two transitions, with melting temperature around $70^{\circ} \mathrm{C}$ and $82^{\circ} \mathrm{C}$. The unfolding of Fab fragment normally occurs at lower temperatures $70^{\circ} \mathrm{C}$, whereas $82^{\circ} \mathrm{C}$ for Fc fragment [41]. Based on this finding, it may be speculated that the first and second unfolding events in the human mAbs are analogous with mouse mAbs. Therefore, human mAbs D2 and F9 may be expected to share a similar stability with mouse mAb C1-13 although only one peak was observed in mouse antibody. In addition to different melting profiles, the sequence of the variable domains is another factor potentially affecting the stability of the Fab fragment from either human or mouse [47]. Overall, the observation of melting point for mouse mAb C1-13, and human mAbs D2 and F9 suggested the mAbs produced in this study are more heat stable (by DSC analysis), but in practical terms when comparing stability at $25^{\circ} \mathrm{C}$ and $37^{\circ} \mathrm{C}$ all three mAbs exhibit similar stability.
In summary, phage display is a promising tool that allows the selection of new binders by undergoing iterative rounds of biopanning. In this study, two scFv clones isolated from human $\mathrm{scFv}$ naïve library were shown to have high affinity and specificity against PfHRP2 proteins. The binding efficacy of these recombinant mAbs was demonstrated to be comparable to commercial mAb C113. However, this system has some disadvantages, including duration of expression and expense of the eukaryotic expression system that may inhibit the use of the current system for manufacture of mAbs for malaria RDTs. Therefore, alternative expression method may be preferable. In addition, false positive results that occurred between native human RBC with anti-human antibodies, suggesting human Fc region might not be an ideal detection region for $\mathrm{mAb}$ recognition. Thus, tagging of the $\mathrm{mAb}$, for example by biotinylation, may potentially reduce the cross-reactivity problem.

\section{Conclusions}

Five rounds of biopanning resulted in selection of two high affinity clones from a naïve library. Recombinant mAbs D2 and F9, expressed by mammalian cells, are high quality mAbs which exhibited excellent binding capability to rPfHRP2. These antibodies were also demonstrated to have specificity and sensitivity comparable to commercial mAb $\mathrm{C} 1-13$ but with potentially better thermostability. Therefore, the mAbs produced in this study may be suitable for evaluation by undergoing field test in different malaria endemic regions in a prototype test kit.

\section{Additional files}

Additional file 1: Cross-reactivity determination of recombinant mAbs against three different malaria biomarkers in Western blot analysis. Cross-reactivity determination of recombinant mAbs against three different malaria biomarkers in Western blot analysis. Lane 1 : rPfHRP2; Lane 2: rPfLDH; Lane 3: rPvAldolase. The molecular weight and purity of each malaria biomarker is shown in panel $\mathrm{A}$. The reactivity of mAbs D2, F9, and C1-13 are represented by panel B, C, and D, respectively.

Additional file 2: Cross-reactivity determination of recombinant mAbs against three different malaria biomarkers in ELISA analysis. The reactivity of $m A b s D 2, F 9$, and $C 1-13$ are represented by panel $A, B$, and $C$, respectively.

Additional file 3: The melting point for three $\mathrm{mAbs}$ in $\mathrm{PBS} \mathrm{pH} 7.2$ buffer by DSC analysis. Calculated Tms for $1 \mathrm{mg} / \mathrm{mL} \mathrm{mAb}$ C1-13 (purple) was $72^{\circ} \mathrm{C} ; 1 \mathrm{mg} / \mathrm{mL} \mathrm{mAb}$ D2 (green) had 2 peaks at Tms of $72^{\circ} \mathrm{C}$ and $82^{\circ} \mathrm{C}$; and $0.5 \mathrm{mg} / \mathrm{mL}$ of mAb F9 (magenta) had two peaks at Tms of $73^{\circ} \mathrm{C}$ and $80^{\circ} \mathrm{C}$. mAbs D2 and F9 precipitated at high temperatures indicated by sharp peak decline and negative $\mathrm{Cp}$ values. Control $\mathrm{mAb}$ C1-13 did not precipitate indicated by $\mathrm{Cp}$ values returning to baseline following Tm peak.

Additional file 4: Determination of heat stability at different temperatures and durations. Dot blot was used to determine the heat stability of mAbs on a nitrocellulose membrane immobilized with two-fold serially diluted rPfHRP2 (starting at $1 \mu \mathrm{g} / \mathrm{mL}$ ). The tested mAbs 
were incubated at $25^{\circ} \mathrm{C}$ for 7 days (A) and, at $37^{\circ} \mathrm{C}$ for 30 days (B) prior to hybridize to $r$ PfHRP2 proteins.

\section{Additional file 5: Determination of mAbs affinity by Octet}

sensogram. Sensogram showing two mAbs binding to serially diluted rPfHRP2 proteins from $600 \mathrm{nM}$ to $0.0061 \mathrm{nM}$. mAb D2 is represented in panel A. mAb F9 is represented in panel B. Coloured lines represent the binding interactions of $m A b$ to different concentration of rPfHRP2. Red lines represent the statistical fitting of curves.

\section{Abbreviations}

BSA: Bovine serum albumin; CDRs: Complementarity determining regions; CV: Coefficient of variation; FW: Framework; HPLC: High-performance liquid chromatography; HRP: Horseradish peroxidase; IgG: Immunoglobulin G; mAb: Monoclonal antibody; PfHRP2: P. falciparum histidine-rich protein 2; RBC: Red blood cell; RDTs: Rapid diagnostic tests; rPfHRP2: Recombinant histidine-rich protein 2; scFv: Single chain variable fragment; VH: Variable heavy; VL: Variable light.

\section{Competing interests}

The authors declare that they have no competing interests.

\section{Authors' contributions}

All authors made contribution to this study. $\mathrm{HL}$ and $\mathrm{MJ}$ conceived the general project study. JM, QC and SM coordinated the project and led manuscript writing. All authors have read and approved the final manuscript.

\section{Acknowledgements}

We gratefully thank Dr Christopher Howard from AIBN, University of Queensland for assistance with production of recombinant mAbs and conducting DSC experiments. Dr Katharine Trenholme from Malaria Biology Lab, QIMR Berghofer Medical Research Institute is acknowledged for providing the $P$. falciparum-infected red blood cells. HL is supported by a Malaysian Government and Universiti Sains Malaysia ASTS scholarship. We would like to thank Dr Martin Bubb, National Products Institute, South Africa for providing mAb C1-13. Dr Qin Cheng is from The Australian Defence Force Joint Health Command. The opinions expressed herein are those of the authors and do not necessarily reflect those of the Australian Defence Force Joint Health Command.

\section{Author details}

${ }^{1}$ QIMR Berghofer Medical Research Institute, Brisbane, Australia. ${ }^{2}$ School of Medicine, University of Queensland, Brisbane, Australia. Institute for Research in Molecular Medicine (INFORMM), Universiti Sains Malaysia, Penang, Malaysia. ${ }^{4}$ Australian Institute for Bioengineering \& Nanotechnology (AIBN), University of Queensland, Brisbane, Australia. ${ }^{5}$ Drug Resistance and Diagnostics, Australian Army Malaria Institute, Brisbane, Australia.

Received: 2 May 2014 Accepted: 30 June 2014

Published: 18 July 2014

\section{References}

1. WHO: World Malaria Report 2012. Geneva: WHO Press; 2012.

2. Bukirwa H: Assessing rapid diagnostic tests for malaria. Cochrane Database Syst Rev 2011, 9:ED000031.

3. Yukich J, D'Acremont V, Kahama J, Swai N, Lengeler C: Cost savings with rapid diagnostic tests for malaria in low-transmission areas: evidence from Dar es Salaam, Tanzania. Am J Trop Med Hyg 2010, 83:61-68.

4. Bell D: Malaria rapid diagnostic tests: one size may not fit all. Clin Microbiol Rev 2002, 15:771. discussion 771-772.

5. Howard RJ, Uni S, Aikawa M, Aley SB, Leech JH, Lew AM, Wellems TE, Rener J, Taylor DW: Secretion of a malarial histidine-rich protein (Pf HRP II) from Plasmodium falciparum-infected erythrocytes. J Cell Biol 1986, 103:1269-1277.

6. Wellems TE, Howard RJ: Homologous genes encode two distinct histidine-rich proteins in a cloned isolate of Plasmodium falciparum. Proc Natl Acad Sci U S A 1986, 83:6065-6069.

7. Tahar R, Sayang C, Ngane Foumane V, Soula G, Moyou-Somo R, Delmont J, Basco LK: Field evaluation of rapid diagnostic tests for malaria in Yaounde, Cameroon. Acta Trop 2013, 125:214-219.
8. Kattenberg $\mathrm{JH}$, Tahita $\mathrm{CM}$, Versteeg IA, Tinto $\mathrm{H}$, Traore-Coulibaly M, Schallig $H D$, Mens PF: Antigen persistence of rapid diagnostic tests in pregnant women in Nanoro, Burkina Faso, and the implications for the diagnosis of malaria in pregnancy. Trop Med Int Health 2012, 17:550-557.

9. Tjitra E, Suprianto S, McBroom J, Currie BJ, Anstey NM: Persistent ICT malaria P.f/P.v panmalarial and HRP2 antigen reactivity after treatment of Plasmodium falciparum malaria is associated with gametocytemia and results in false-positive diagnoses of Plasmodium vivax in convalescence. J Clin Microbiol 2001, 39:1025-1031.

10. Bell D, Wongsrichanalai C, Barnwell JW: Ensuring quality and access for malaria diagnosis: how can it be achieved? Nat Rev Microbiol 2006, 4:682-695.

11. Murray CK, Gasser RA Jr, Magill AJ, Miller RS: Update on rapid diagnostic testing for malaria. Clin Microbiol Rev 2008, 21:97-110.

12. Reyburn H, Mbakilwa H, Mwangi R, Mwerinde O, Olomi R, Drakeley C, Whitty CJ: Rapid diagnostic tests compared with malaria microscopy for guiding outpatient treatment of febrile illness in Tanzania: randomised trial. BMJ 2007, 334:403.

13. Hussack G, Arbabi-Ghahroudi M, Mackenzie CR, Tanha J: Isolation and characterization of Clostridium difficile toxin-specific single-domain antibodies. Methods Mol Biol 2012, 911:211-239.

14. Liu Y, Regula LK, Stewart A, Lai JR: Synthetic Fab fragments that bind the HIV-1 gp41 heptad repeat regions. Biochem Biophys Res Commun 2011, 413:611-615.

15. Shui X, Huang J, Li YH, Xie PL, Li GC: Construction and selection of human Fab antibody phage display library of liver cancer. Hybridoma (Larchmt) 2009, 28:341-347.

16. Sowa KM, Cavanagh DR, Creasey AM, Raats J, McBride J, Sauerwein R, Roeffen WF, Arnot DE: Isolation of a monoclonal antibody from a malaria patient-derived phage display library recognising the Block 2 region of Plasmodium falciparum merozoite surface protein-1. Mol Biochem Parasitol 2001, 112:143-147.

17. Yang GH, Yoon SO, Jang MH, Hong HJ: Affinity maturation of an anti-hepatitis B virus PreS1 humanized antibody by phage display. J Microbiol 2007, 45:528-533.

18. Smith GP: Filamentous fusion phage: novel expression vectors that display cloned antigens on the virion surface. Science 1985, 228:1315-1317.

19. Azzazy HM, Highsmith WE Jr: Phage display technology: clinical applications and recent innovations. Clin Biochem 2002, 35:425-445.

20. Nelson AL, Dhimolea E, Reichert JM: Development trends for human monoclonal antibody therapeutics. Nat Rev Drug Discov 2010, 9:767-774

21. Reichert JM: New biopharmaceuticals in the USA: trends in development and marketing approvals 1995-1999. Trends Biotechnol 2000, 18:364-369.

22. Baker J, McCarthy J, Gatton M, Kyle DE, Belizario V, Luchavez J, Bell D, Cheng $\mathrm{Q}$ : Genetic diversity of Plasmodium falciparum histidine-rich protein 2 (PfHRP2) and its effect on the performance of PfHRP2-based rapid diagnostic tests. J Infect Dis 2005, 192:870-877.

23. Lee N, Gatton ML, Pelecanos A, Bubb M, Gonzalez I, Bell D, Cheng Q, McCarthy JS: Identification of optimal epitopes for Plasmodium falciparum rapid diagnostic tests that target histidine-rich proteins 2 and 3. J Clin Microbiol 2012, 50:1397-1405.

24. Sheets $M D$, Amersdorfer $P$, Finnern $R$, Sargent $P$, Lindquist $E$, Schier $R$, Hemingsen G, Wong C, Gerhart JC, Marks JD: Efficient construction of a large nonimmune phage antibody library: the production of high-affinity human single-chain antibodies to protein antigens. Proc Natl Acad Sci U S A 1998, 95:6157-6162

25. Retter I, Althaus HH, Munch R, Muller W: VBASE2, an integrative V gene database. Nucleic Acids Res 2005, 33:D671-D674.

26. Jones ML, Seldon T, Smede M, Linville A, Chin DY, Barnard R, Mahler SM, Munster D, Hart D, Gray PP, Munro TP: A method for rapid, ligation-independent reformatting of recombinant monoclonal antibodies. J Immunol Methods 2010, 354:85-90.

27. Kattenberg JH, Versteeg I, Migchelsen SJ, Gonzalez IJ, Perkins MD, Mens PF Schallig HD: New developments in malaria diagnostics: monoclonal antibodies against Plasmodium dihydrofolate reductase-thymidylate synthase, heme detoxification protein and glutamate rich protein. MAbs 2012, 4:120-126.

28. Sumanadasa SD, Goodman CD, Lucke AJ, Skinner-Adams T, Sahama I, Haque A, Do TA, McFadden GI, Fairlie DP, Andrews KT: Antimalarial activity of the 
anticancer histone deacetylase inhibitor SB939. Antimicrob Agents Chemother 2012, 56:3849-3856.

29. Beadle C, Long GW, Weiss WR, McElroy PD, Maret SM, Oloo AJ, Hoffman SL: Diagnosis of malaria by detection of Plasmodium falciparum HRP-2 antigen with a rapid dipstick antigen-capture assay. Lancet 1994, 343:564-568.

30. Shiff CJ, Premji Z, Minjas JN: The rapid manual ParaSight-F test. A new diagnostic tool for Plasmodium falciparum infection. Trans $R$ Soc Trop Med Hyg 1993, 87:646-648.

31. Butler D: Global fund changes tack on malaria therapy. Nature 2004, 429:588.

32. Albertini A, Lee E, Coulibaly SO, Sleshi M, Faye B, Mationg ML, Ouedraogo K, Tsadik AG, Feleke SM, Diallo I, Gaye O, Luchavez J, Bennett J, Bell D: Malaria rapid diagnostic test transport and storage conditions in Burkina Faso, Senegal, Ethiopia and the Philippines. Malar J 2012, 11:406.

33. Moody A: Rapid diagnostic tests for malaria parasites. Clin Microbiol Rev 2002, 15:66-78.

34. List of known commercially available antigen-detecting malaria RDTs. [http://www.wpro.who.int/malaria/sites/rdt/]

35. Jorgensen P, Chanthap L, Rebueno A, Tsuyuoka R, Bell D: Malaria rapid diagnostic tests in tropical climates: the need for a cool chain. Am J Trop Med Hyg 2006, 74:750-754.

36. Ravaoarisoa E, Zamanka H, Fusai T, Bellalou J, Bedouelle $H$, Mercereau-Puijalon O, Fandeur T: Recombinant antibodies specific for the Plasmodium falciparum histidine-rich protein 2. MAbs 2010 2:416-427.

37. Rock EP, Marsh K, Saul AJ, Wellems TE, Taylor DW, Maloy WL, Howard RJ: Comparative analysis of the Plasmodium falciparum histidine-rich proteins HRP-I, HRP-II and HRP-III in malaria parasites of diverse origin. Parasitology 1987, 95(Pt 2):209-227.

38. Lee N, Baker J, Andrews KT, Gatton ML, Bell D, Cheng Q, McCarthy J: Effect of sequence variation in Plasmodium falciparum histidine- rich protein 2 on binding of specific monoclonal antibodies: Implications for rapid diagnostic tests for malaria. J Clin Microbiol 2006, 44:2773-2778.

39. Zerpa NC, Wide A, Noda J, Bermudez H, Pabon R, Noya OO: Immunogenicity of synthetic peptides derived from Plasmodium falciparum proteins. Exp Parasitol 2006, 113:227-234

40. Baker J, Ho MF, Pelecanos A, Gatton M, Chen N, Abdullah S, Albertini A, Ariey F, Barnwell J, Bell D, Cunningham J, Djalle D, Echeverry DF, Gamboa D, Hii J, Kyaw MP, Luchavez J, Membi C, Menard D, Murillo C, Nhem S, Ogutu B, Onyor P, Oyibo W, Wang S, McCarthy J, Cheng Q: Global sequence variation in the histidine-rich proteins 2 and 3 of Plasmodium falciparum: implications for the performance of malaria rapid diagnostic tests. Malar J 2010, 9:129.

41. Tischenko VM, Abramov VM, Zav'yalov VP: Investigation of the cooperative structure of Fc fragments from myeloma immunoglobulin G. Biochemistry 1998, 37:5576-5581.

42. Bruhns P: Properties of mouse and human IgG receptors and their contribution to disease models. Blood 2012, 119:5640-5649.

43. Yasui $H$, Ito W, Kurosawa Y: Effects of substitutions of amino acids on the thermal stability of the Fv fragments of antibodies. FEBS Lett 1994, 353:143-146.

44. Perchiacca JM, Tessier PM: Engineering aggregation-resistant antibodies. Annu Rev Chem Biomol Eng 2012, 3:263-286.

45. Welfle K, Misselwitz R, Hausdorf G, Hohne W, Welfle H: Conformation, $\mathrm{pH}$-induced conformational changes, and thermal unfolding of anti-p24 (HIV-1) monoclonal antibody CB4-1 and its Fab and Fc fragments. Biochim Biophys Acta 1999, 1431:120-131.

46. Jea W: Using gifferential scanning calorimetry in understanding the correlation between thermal stability and protein stability: a case study. MicroCal 2007, 1:1-6.

47. Ionescu RM, Vlasak J, Price C, Kirchmeier M: Contribution of variable domains to the stability of humanized IgG1 monoclonal antibodies. J Pharm Sci 2008, 97:1414-1426.

doi:10.1186/1475-2875-13-277

Cite this article as: Leow et al:: Production and characterization of specific monoclonal antibodies binding the Plasmodium falciparum diagnostic biomarker, histidine-rich protein 2. Malaria Journal 2014 13:277.

\section{Submit your next manuscript to BioMed Central and take full advantage of:}

- Convenient online submission

- Thorough peer review

- No space constraints or color figure charges

- Immediate publication on acceptance

- Inclusion in PubMed, CAS, Scopus and Google Scholar

- Research which is freely available for redistribution 